\title{
Vaccines and drugs against Neospora caninum, an important apicomplexan causing abortion in cattle and other farm animals
}

This article was published in the following Dove Press journal:

Reports in Parasitology

18 September 2015

Number of times this article has been viewed

\section{Andrew Hemphill \\ Joachim Müller}

Institute of Parasitology, Vetsuisse Faculty, University of Bern, Bern, Switzerland
Correspondence: Andrew Hemphill Institute of Parasitology, Vetsuisse Faculty, University of Bern, LänggassStrasse 122, CH-30I2 Bern, Switzerland $\mathrm{Tel}+4|3| 63 \mid 2384$

Fax +4I 3| 63। 2477

Email andrew.hemphill@vetsuisse.unibe.ch
Abstract: The apicomplexan parasite Neospora caninum represents an important abortioncausing parasite in cattle. The economic impact of neosporosis has led to considerable investments to develop vaccines that would prevent infection and abortion. Live-attenuated vaccines have been shown to confer some protection against $N$. caninum infection, but may cause problems due to regulatory issues and other drawbacks. Therefore, efforts have been undertaken to develop recombinant subunit vaccines based on antigens involved in adhesion/invasion or other parasite-host cell interaction processes. Concerning chemotherapeutical agents, the currently known arsenal of active drugs that act against $N$. caninum is limited to a small number of compounds with suitable in vitro properties including low inhibition constants, parasitocidal effects, and low cytotoxicity. For in vivo studies, mostly small laboratory animal models that mimic cerebral infection, acute disease, and fetal loss upon infection during pregnancy have been applied for the assessment of vaccines or drug candidates. However, only a small number of recombinant vaccines and drug candidates have met the expectations, and small laboratory models for neosporosis need to be standardized in order to be able to compare the results of different laboratories. Few vaccines and compounds have made it into trials involving ruminant models such as cattle or sheep, including live-attenuated vaccines and the anticoccidial drug toltrazuril. We here summarize the current status of vaccine and drug development for neosporosis.

Keywords: neosporosis, anti-infective agents, chemotherapy, immunotherapy, vaccine, drug target

\section{Introduction}

Apicomplexan parasites are responsible for a variety of diseases in humans, pets, and/ or farm animals, and are thus of high medical, veterinary, and economic importance. Babesia, Besnoitia, Cryptosporidium, Eimeria, Neospora, Sarcocystis, Theileria, and Toxoplasma are all relevant in the context of causing diseases in farm animals, with a great socioeconomic impact worldwide. ${ }^{1}$ Neospora caninum is phylogenetically most closely related to Toxoplasma gondii, but distinct from Toxoplasma with regard to several biological features including the life cycle, host range, and pathogenicity. ${ }^{2,3}$ Canids, namely dogs, wolves, dingoes, and coyotes, represent definitive hosts of $N$. caninum, ${ }^{4}$ and besides cattle also sheep, goats, and many more species have been reported as intermediate hosts. ${ }^{4,5}$ Humans do - to our present knowledge - not serve as intermediate hosts for $N$. caninum. ${ }^{6}$ Three infective stages of $N$. caninum have been identified to date. These are i) tachyzoites, which represent the disease-causing and rapidly proliferating stage, which can be transmitted vertically from dam to offspring 
during pregnancy; ii) slowly replicating bradyzoites that form tissue cysts, and which are orally infective; and iii) sporozoites enclosed in oocysts, the end products of a sexual process taking place in the intestine of the definitive host followed by sporulation in the environment, which are also orally infective. Although a sylvatic cycle for $N$. caninum has been demonstrated, ${ }^{7,8}$ its importance as reservoir for the transmission to domestic animals has not been definitely elucidated.

Neosporosis in cattle causes annual losses of approximately 1.3 billion US dollars through abortion, stillbirth, or birth of weak offspring. ${ }^{9}$ In addition, $N$. caninum infection can result in birth of clinically healthy, but persistently infected calves, which in turn then vertically transmit the parasite to the next generation. Control options to limit the economic impact of neosporosis that have been proposed and modeled include i) testing and culling of seropositive animals, ii) discontinued breeding with offspring from seropositive cows, iii) vaccination of susceptible and infected animals, and iv) chemotherapeutical treatment of calves from seropositive cows. ${ }^{10,11}$ However, the most effective option is not always the most economic one ${ }^{12}$ and the suitability of any of these options, including considerations on potential treatment options for dogs, has to be carefully assessed for each case prior to implementation. ${ }^{10-14}$

In this review, we will focus on the current state of the art of vaccine and drug development against neosporosis, and where appropriate, we will extrapolate to other apicomplexan parasites.

\section{Vaccination against neosporosis}

Considerable efforts have been made to develop vaccines against $N$. caninum, as well as the closely related T. gondii to reduce oocyst shedding in the final hosts (cats for Toxoplasma and canids for Neospora, respectively), and tissue cyst formation in mammals, but to date only a live-attenuated vaccine for prevention of ovine toxoplasmosis (Toxovax ${ }^{\mathrm{TM}}$ ) has been licensed, and it is not approved for use in other species. ${ }^{13}$ As the mathematical modeling of the costs of the management practices used for the control of neosporosis indicate that vaccination could be an efficient intervention strategy, ${ }^{14}$ several research groups have recognized the need for the development of effective vaccines against neosporosis to be used in cattle. ${ }^{15}$

$N$. caninum has developed distinct adaptations to its intracellular lifestyle and efficient mechanisms to achieve host cell invasion and subsequent intracellular survival have evolved. Knowledge of the molecular basis of these processes is essential for understanding the pathogenic mechanisms underlying infection and for designing strategies to combat neosporosis. The postgenomic era of apicomplexan cell biology offers powerful experimental tools that can be exploited to improve our understanding of parasite survival strategies and pathogenicity. ${ }^{16}$

Selected vaccination studies in mice are summarized in Table 1, and respective studies in cattle and other farm animals are compiled in Table 2. These comprise trials using live or attenuated $N$. caninum tachyzoites, tachyzoite extracts, or specific polypeptides expressed in various systems. The experimental design of a typical vaccine trial in the mouse model is as follows: i) animals receive a first immunization and one or two vaccine boosts of the antigen of interested emulsified in a suitable adjuvants. Control animals receive a placebo inoculum; ii) in a nonpregnant model, the animals are then challenged with a given dose of freshly isolated parasites. To assess efficacy in a pregnant model, animals are mated prior to challenge infection. In most cases, cell culture-derived tachyzoites have been used, since access to oocysts is restricted. However, this does not represent the natural infection mode; and iii) parameters linked to neosporosis have been measured, such as survival of dams and offspring, clinical symptoms (most notably due to multiple organ failure at the early time points and neurological symptoms at later stages of infection), parasite burden in different organs, especially the brain, and humoral and cellular immune responses. In the mouse model, transplacental transmission of $N$. caninum to the offspring causes in most cases acute, generalized neosporosis followed by early death of newborns within 30 days. Thus, the mere survival of the newborns during a 4-week period after birth is already a good parameter to measure protection.

Most recombinant subunit vaccine candidates assessed to date have been antigens that represent surface proteins, heat shock proteins, or were derived from proteins that are released from the apicomplexan-specific secretory organelles named micronemes, rhoptries, and dense granules. Most of these antigens were expressed in Escherichia coli, and have been applied either as monovalent vaccines or in different combinations as polyvalent antigen cocktails (Table 1). The selection of suitable vaccine candidates has been largely guided by the idea to target the host cell-parasite interactions that lead to host cell entry. The initial host cell recognition is mediated by parasite surface antigens, while the actual invasion process is dependent on specific molecular interactions between host receptors and parasite ligands secreted from micronemes, rhoptries, and 
Table I Summary of selected vaccine studies involving neosporosis in mice

\begin{tabular}{|c|c|c|c|c|}
\hline Vaccine & Ref & Year & Setup & Results \\
\hline Nc-I tachyzoites & 50 & 1998 & $\begin{array}{l}\text { A/J, Balbc, C57BL/6; vaccinated with live Nc-I } \\
\text { tachyzoites; challenge after various days with } \\
\text { Toxoplasma gondii tachyzoites. }\end{array}$ & $\begin{array}{l}\text { Complete protection in mice vaccinated } \\
\text { with Neospora caninum against acute } \\
\text { infection by } T \text {. gondii. Early stimulation of } \\
C D 8^{+} T \text {-cells. }\end{array}$ \\
\hline $\begin{array}{l}\text { SAGI, SRS2 (rE, DNA) alone or } \\
\text { combined; crude somatic antigen }\end{array}$ & 51 & 2003 & $\begin{array}{l}\text { C57BL/6, vaccine }+ \text { Ribi }(2 \times) \text {, challenge } 28 \text { days } \\
\text { after the first injection (proteins). pcDNA } \\
\text { vector with genes im, challenge } 69 \text { days after } \\
\text { first injection. Euthanasia after } 21 \text { days. }\end{array}$ & $\begin{array}{l}\text { Protection with crude antigen. No } \\
\text { protection with recombinant antigens as } \\
\text { compared to adjuvant control. Protection } \\
\text { with pcDNA in combination with } \\
\text { recombinant antigens. }\end{array}$ \\
\hline MIC3 (rE) & 52 & 2003 & $\begin{array}{l}\text { C57BL/6, vaccinated with MIC } 3+\text { Ribi }(3 \times) \text {, } \\
\text { challenge } 7 \text { days after last boost, euthanasia } \\
\text { after } 21 \text { days. }\end{array}$ & $\begin{array}{l}\text { Reduced cerebral infection in MIC3 } \\
\text { vaccinated mice as compared to adjuvant } \\
\text { control. Th2-type humoral response } \\
\text { associated with protection. }\end{array}$ \\
\hline $\mathrm{MICl}(\mathrm{rE}$ and DNA) & 53 & 2005 & $\begin{array}{l}\text { C57BL/6, recMICI ( } 3 \times \text { ip), pcDNA-MICI } \\
(3 \times \mathrm{im}) \text { alone or in combination. Challenge, } \\
\text { euthanasia after } 2 \text { I days. }\end{array}$ & $\begin{array}{l}\text { No clinical symptoms in vaccinated } \\
\text { mice. Cerebral infection reduced in mice } \\
\text { vaccinated with recombinant protein, } \\
\text { enhanced in group with combined } \\
\text { vaccination. }\end{array}$ \\
\hline SRS2 (native) & 54 & 2005 & $\begin{array}{l}\text { BALB/c, vaccinated with native protein. Mating, } \\
\text { challenge during pregnancy. }\end{array}$ & $\begin{array}{l}\text { Decreased frequency of transmission in } \\
\text { vaccinated dams, associated with Th2- } \\
\text { type immune response. }\end{array}$ \\
\hline Nc-I tachyzoites ( $\gamma$-irradiated) & 55 & 2006 & $\begin{array}{l}\text { C57BL/6, vaccinated with irradiated } \\
\text { tachyzoites }(2 \times) \text {. Challenge } 6 \text { weeks after last } \\
\left.\text { boost (lethal, } 10^{7} \text {; sublethal, } 10^{6}\right) \text {, } \\
\text { euthanasia } 25 \text { days after }\end{array}$ & $\begin{array}{l}\text { All lethally challenged control mice } \\
\text { died within I week, all vaccinated mice } \\
\text { survived. Protection associated with } \\
\text { mixed ThI/Th2 response. }\end{array}$ \\
\hline
\end{tabular}

MICI, MIC3, GRA2, GRA6, SRS2 $56 \quad 2007 \quad$ C57BL/6, vaccinated with live B. abortus

(in Brucella abortus)

MICI, MIC3, GRA2, GRA6, SRS2

(in B. abortus)

MIC4 (native, rE, DNA)

ROP2 (rE)

$\mathrm{ROP} 2+\mathrm{MICl}+\mathrm{MIC3}$

Nc expressing TgSAGI

PDI, ROP2, MAGI (rE)

Nc expressing NcSAG4
62

2010

2007

2007

expressing the antigens $(2 \times)$,

lethal challenge $x$ days after last boost.

Euthanasia after 28 days.

C57BL/6, vaccinated with live $B$. abortus expressing the antigens $(2 \times)$, mating, sublethal challenge. Euthanasia of pups after 21 days. C57BL/6, vaccinated $3 \times$ in 4-week interval, sublethal challenge, euthanasia after 21 days.

$19 \quad 2008$
mice after 30 days.

BALB/c, vaccinated $2 \times$ with $10^{5} \mathrm{Nc}-1$ expressing TgSAGI or GFP. Challenge 4 weeks after last boost with $T$. gondii (500 tachyzoites). C57/BL6, vaccinated with saponin as adjuvant (ip) or intranasally (in) with cholera toxin as adjuvant ( $3 \times, 15$ days intervals). Challenge

2 weeks after last boost, euthanasia after 28 days. Female BALB/c, vaccinated twice with $\mathrm{Nc}$ - I expressing SAG4, some were mated, challenge at day 7 of gestation.
All control mice died within 8 days.

Complete protection by $\mathrm{MICl}$ and GRA6.

Protection against vertical transmission by B. abortus expressing antigens.

Mice of all vaccinated groups showed neosporosis symptoms and had an increased mortality as compared to the control group.

No symptoms in vaccinated mice, reduced parasite burden in brains of vaccinated mice. Thl- or Th2-type humoral response depending on the adjuvant.

Reduced vertical transmission by ROP2 alone or in combination. Humoral and cytokine responses associated with a Th2 immune response.

Moderate protection by Nc/GFP, good protection by $\mathrm{Nc} / \mathrm{TgSAG}$ I. Immune response ThI-dominant.

Reduced cerebral loads with ROPI (ip, in) and PDI (in only). Protection against clinical symptoms only by PDI (in).

Protection against vertical transmission by $\mathrm{Nc}-\mathrm{I}$ wt and $\mathrm{Nc}-\mathrm{I}$ expressing SAG4, not associated with constant ThI- or Th2type immune response. 
Table I (Continued)

\begin{tabular}{|c|c|c|c|c|}
\hline Vaccine & Ref & Year & Setup & Results \\
\hline Cyclophilin, SRS2 (rE) & 64 & 2011 & $\begin{array}{l}\text { Female BALB/c, antigens alone or in } \\
\text { combination with adjuvants (sc, } 2 \times, 2 \text {-week } \\
\text { interval). Control with irrelevant bacterial } \\
\text { antigen. Challenge } 3 \text { weeks after last boost. } \\
\text { Euthanasia } 3 \text { weeks after challenge. }\end{array}$ & $\begin{array}{l}\text { Humoral response against antigens. } \\
\text { Higher protection against cerebral } \\
\text { infection when cyclophilin was present. } \\
\text { Lower protection with SRS2 alone. }\end{array}$ \\
\hline MICI-MIC3-ROP2 (chimeric, rE) & 65 & 2011 & $\begin{array}{l}\text { Female BALB/c, immunized with combinations } \\
\text { of antigenic domains from } \mathrm{MICI}, \mathrm{MIC} 3 \text {, and } \\
\text { ROP2 with saponin as adjuvant (ip, } 3 \times \text {, 2-week } \\
\text { interval). Challenge } 2 \text { weeks after last boost. } \\
\text { Euthanasia } 36 \text { days post-challenge. }\end{array}$ & $\begin{array}{l}\text { Complete protection by one combination } \\
\text { only (MIC3-I-R), correlated with lower } \\
\text { parasite load in brains in nonpregnant } \\
\text { mice. }\end{array}$ \\
\hline Nc tachyzoites (live) & 66 & 2012 & $\begin{array}{l}\text { Female BALB/c, immunized with live Nc Spain } \\
\mathrm{H} \text {-I tachyzoites (sc, } 2 \times \text { at } 3 \text {-week interval). } \\
\text { For pregnant model, mating, challenge ad mid } \\
\text { gestation with Nc Liv. }\end{array}$ & $\begin{array}{l}\text { Reduction of neonatal mortality, } \\
\text { reduction of vertical transmission, } \\
\text { and lower cerebral parasite load in } \\
\text { nonpregnant mice. }\end{array}$ \\
\hline GRA7, SAG4, BSR4, SRS9 (rE) & 67 & 2012 & $\begin{array}{l}\text { Female BALB/c, pregnant, nonpregnant. } \\
\text { Vaccinated with recombinant proteins } \\
\text { encapsulated in poly-epsilon-caprolactone. }\end{array}$ & $\begin{array}{l}\text { High morbidity and mortality. No } \\
\text { protection against vertical transmission. } \\
\text { Low IFN- } \gamma \text { levels. }\end{array}$ \\
\hline Nc tachyzoite extract & 68 & 2012 & $\begin{array}{l}\text { BALB/c, vaccinated with different amounts } \\
\text { of extract formulated with various adjuvants }\end{array}$ & $\begin{array}{l}\text { Immune responses depend on } \\
\text { formulation, no protection. }\end{array}$ \\
\hline
\end{tabular}

MICI-MIC3-ROP2 chimeric ( $r E) \quad 69 \quad 2013 \quad \begin{aligned} & \text { post-challenge. } \\ & \text { BALB/c, vaccine + saponin or Freund's } \\ & \text { incomplete }(3 \times) \text {, pregnant. }\end{aligned}$

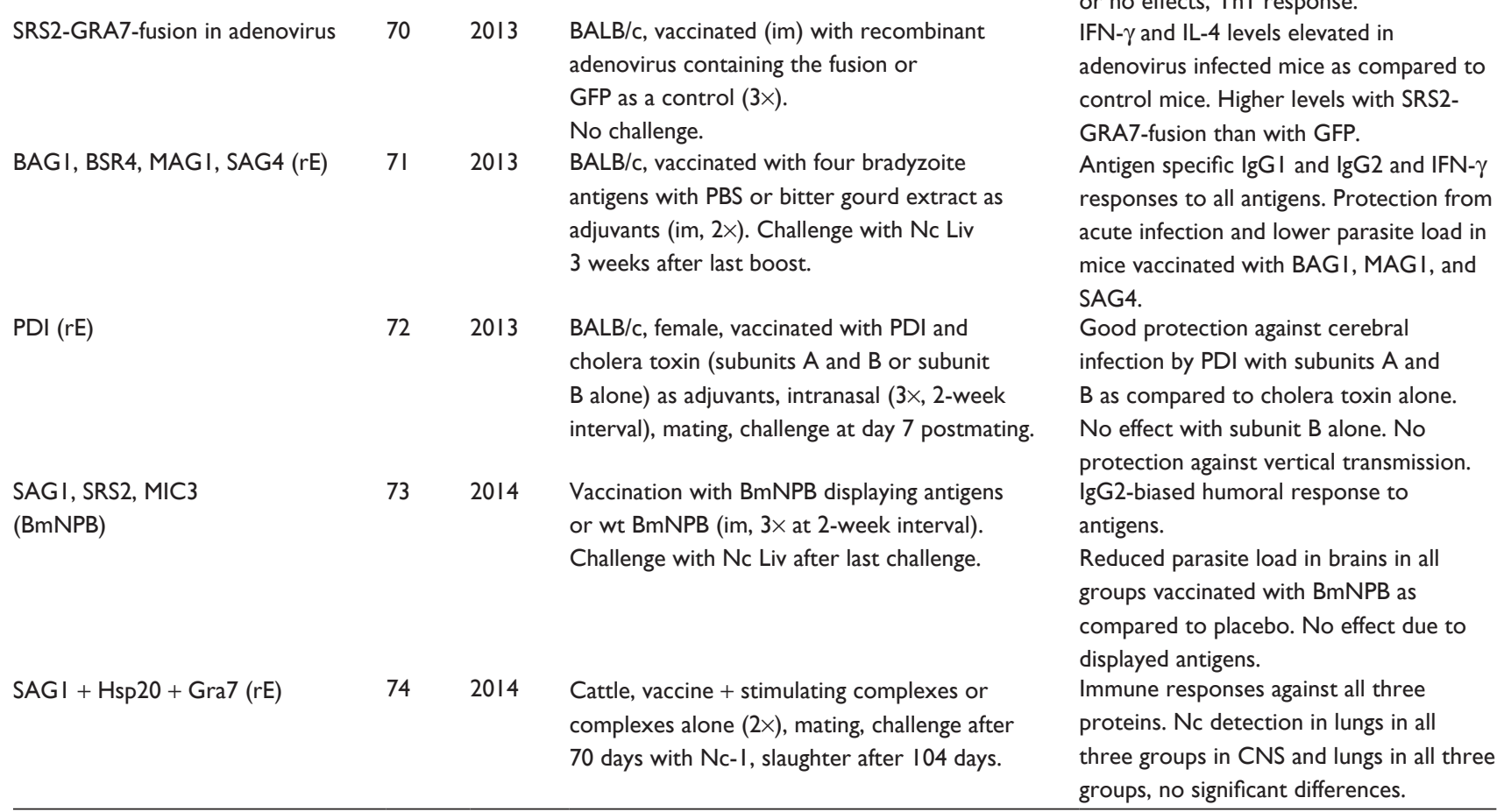

Abbreviations: BmNPB, Bombyx mori nucleopolyhedrovirus; CNS, central nervous system; im, intramuscular; ip, intraperitoneal; sc, subcutaneous; rE, recombinantly expressed in Escherichia coli; DNA, DNA vaccine; Ref, reference; wt, wild type; PDI, protein disulfide isomerase; PBS, phosphate buffered saline; Nc, Neospora caninum; Nc Liv, N. caninum Liverpool isolate.

dense granules. The timely release of these ligands from apical organelles to the parasite surface is crucial for receptor engagement and invasion. ${ }^{17}$ Therefore, the majority of antigens investigated to date have originated from selected surface-associated or secreted proteins. At this point, it is noteworthy to mention that a mere database-dependent research for vaccine candidates may lead on the wrong track. An example is the rhoptry protein ROP18. It is a pseudogene in $N$. caninum, but expressed in the closely related T. gondii. $N$. caninum expressing TgROP18 as a 
Table 2 Summary of selected vaccine studies against neosporosis in farm animals

\begin{tabular}{|c|c|c|c|c|}
\hline Vaccine & Ref & Year & Setup & Results \\
\hline SRS2 expressed in CHV & 75 & 2000 & $\begin{array}{l}\text { Dogs immunized with inactivated } \mathrm{CHV} \\
\text { expressing SRS } 2 \text {. No challenge. }\end{array}$ & IgG production against SRS2. \\
\hline Neospora caninum tachyzoites (killed) & 76 & 2003 & $\begin{array}{l}\text { Seronegative ewes, vaccinated with } \\
\text { tachyzoites + adjuvant }(2 \times) . \text { Challenge } \\
\text { during pregnancy. }\end{array}$ & $\begin{array}{l}\text { Humoral response against } N \text {. caninum in } \\
\text { vaccinated ewes higher than in control ewes. } \\
\text { Lower } N \text {. caninum DNA levels in lambs from } \\
\text { vaccinated ewes. }\end{array}$ \\
\hline Natural infection by $N$. caninum & 77 & 2003 & $\begin{array}{l}\text { Naturally infected and naïve cows, } \\
\text { challenged at week } 10 \text { of gestation. }\end{array}$ & $\begin{array}{l}\text { Natural infection protects against abortion } \\
\text { induced by challenge, but not against vertical } \\
\text { transmission. }\end{array}$ \\
\hline N. caninum tachyzoites (killed) & 78 & 2004 & $\begin{array}{l}\text { Ewes, vaccinated with tachyzoites }+ \\
\text { adjuvant }(2 \times) \text {. Challenge } 30 \text { days } \\
\text { after last boost. }\end{array}$ & $\begin{array}{l}\text { Protection against abortion, but not against } \\
\text { vertical transmission. }\end{array}$ \\
\hline N. caninum tachyzoites (killed) & 79 & 2004 & Field trial with dairy cattle. No challenge. & $\begin{array}{l}\text { Reduction of abortion from } 20 \% \text { in the } \\
\text { placebo group to } 11 \% \text { in the vaccinated group. }\end{array}$ \\
\hline N. caninum tachyzoites (killed) & 80 & 2012 & $\begin{array}{l}\text { Clinical trial with a killed tachyzoite vaccine } \\
\text { (Bovilis Neoguard) on five dairy farms } \\
\text { (sc, } 2 \times, 4 \text {-week interval). }\end{array}$ & $\begin{array}{l}\text { Vaccination increases the risk of vertical } \\
\text { transmission. In one of five herds, vaccination } \\
\text { reduced abortion. }\end{array}$ \\
\hline N. caninum tachyzoite extract & 81 & 2013 & $\begin{array}{l}\text { Cattle, aqueous tachyzoite extract at } \\
\text { various concentrations with soybean based } \\
\text { adjuvant }(2 \times) \text {. No challenge. }\end{array}$ & $\begin{array}{l}\text { Increased IgGI and IFN- } \gamma \text { levels in vaccinated } \\
\text { animals as compared to controls. Stimulation } \\
\text { of CD4(+)-T-cells. }\end{array}$ \\
\hline GRA7 (rE) & 82 & 2013 & $\begin{array}{l}\text { Cattle, Gra7 (50-200 } \mu \mathrm{g}) \text { entrapped } \\
\text { in oligomannose microsomes (sc, } 2 \times) \text {. } \\
\text { Challenge with Nc-I } 27 \text { days after last } \\
\text { boost. Euthanasia at } 85-87 \text { dpi. }\end{array}$ & $\begin{array}{l}\text { IgG and IFN- } \gamma \text { levels increased as compared } \\
\text { to controls. Lower parasite load in brains in } \\
\text { cattle immunized with } 50 \mu \mathrm{g} \text {. }\end{array}$ \\
\hline N. caninum tachyzoites (live) & 83 & 2013 & $\begin{array}{l}\text { Seronegative heifers, immunized with } \\
\text { Nc-Spain } \mathrm{HI}(2 \times) \text {, challenge with Nc-I } \\
\text { postmating }(2 \times) \text {. }\end{array}$ & $\begin{array}{l}\text { Strong IgG and IFN- } \gamma \text { responses } \\
\text { postimmunization. No fetal loss in immunized } \\
\text { but not challenged heifers. In challenged } \\
\text { heifers, } 50 \% \text { protection against fetal loss. }\end{array}$ \\
\hline N. caninum tachyzoites (live or frozen) & 84 & 2013 & $\begin{array}{l}\text { Cattle, } 96 \text { seronegative animals, immunized } \\
\text { with Nc-Nowra (sc or iv, I×), mating. } \\
\text { Pregnant heifers were challenged. }\end{array}$ & $\begin{array}{l}\text { Protection against abortion by vaccination, } \\
\text { best with live tachyzoites iv. }\end{array}$ \\
\hline SAGI + HSP20 + GRA7 & 74 & 2014 & $\begin{array}{l}\text { Pregnant heifers, immunized with } \\
\text { recombinant proteins formulated with } \\
\text { ISCOM (sc, } 2 \times) \text {. Challenge with } \mathrm{Nc} \text { - I } \\
\text { at day } 70 \text { of gestation. }\end{array}$ & $\begin{array}{l}\text { Immune responses against antigens. No IFN- } \gamma \\
\text { response. No protection against vertical } \\
\text { transmission. }\end{array}$ \\
\hline
\end{tabular}

Abbreviations: iv, intravenous; ISCOM, immune stimulating complex; Ref, references; sc, subcutaneous; dpi, days post-infection.

transgenic become more virulent for mice then control transgenics. ${ }^{18}$

Vaccine studies, as presented in Tables 1 and 2, are difficult to compare since the models employed exhibit a large degree of variation, not only with respect to the vaccine to be tested but also with respect to the mouse lines, the Neospora strains, the timespans between vaccination and challenge, challenge and vaccination procedures, vaccine formulations (adjuvants), etc. Nevertheless, some conclusions can be drawn from these studies: i) vaccination with live or attenuated $N$. caninum tachyzoites has emerged to be the most efficient for the protection of mice as well as cattle against acute infection and prevention of vertical transmission; ii) concerning subunit vaccines, some have exhibited good protection (eg, ROP $2^{19}$ ), others were ineffective or even exhibited antiprotective effects (eg, $\mathrm{MIC}^{20}$ ); and iii) it is difficult to establish correlations between effects of a given vaccine and respective immune responses.
As mentioned earlier, the recombinant vaccines used in the studies are based on proteins involved in adhesion and penetration of the host cell. Therefore, it cannot be excluded that a protective effect of antibodies raised against these proteins is due to a direct impairment of adhesion and invasion by the parasite ${ }^{21}$ rather than due to the stimulation of a specific cellular immune response. Since these effects could be mimicked (in theory) by directly applying the respective antibodies, one would speak about immunotherapy rather than vaccination. ${ }^{22}$ Another difficulty in interpreting the results with recombinant vaccines comes from the fact that many of them were expressed in E. coli and affinity purified from crude extracts. Therefore, contaminations with immune-modulating agents from bacterial origin such as lipopolysaccharides cannot be ruled out, and controls with irrelevant proteins expressed in the same system or with lipopolysaccharide-depleted protein fractions ${ }^{23}$ should always 
be included. A fusion of the recombinant antigen with a lipid may facilitate recognition by a toll-like receptor of type 2 and modify the subsequent immune responses. ${ }^{24}$

In mice, studies with vaccines on acute infection models are often terminated after 3-4 weeks post-challenge. It is thus very difficult to extrapolate the immune responses observed in these studies to chronic infections as observed in cattle. Moreover, the immune responses of rodents and ruminants show highly dissimilar characteristics. In mice, elevated levels of IFN- $\gamma$ have been correlated to increased IgG2a and IgG3 production, high IL-4 to increased IgG1 and IgE synthesis, and TGF- $\beta$ to IgA. In cattle, the situation is less polarized, and the classical roles of many cytokines in the laboratory mouse do not extrapolate entirely or at all to cattle. ${ }^{25}$ Therefore, a suitable approach for the selection of suitable vaccine candidates would be to perform in vitro assays with bovine CD4(+) cytotoxic lymphocytes, as done by Staska et al. ${ }^{26}$ The candidate polypeptides inducing the highest level of IFN- $\gamma$ secretion should then be retained for further assessment.

\section{Drugs as an option to intervene in neosporosis?}

Until recently, chemotherapeutic treatment of seropositive farm animals infected with $N$. caninum has not been regarded as an economically viable option, due to the potentially rather long withdrawal period during which milk or meat from drug-treated animals remains unacceptable. ${ }^{27}$ Thus, there are no effective and safe anti-Neospora drugs on the market. However, the inherent difficulty in identifying an efficacious vaccine that has the ability to protect against $N$. caninum infection in pregnant animals renders a chemotherapeutic approach more interesting. Experimental studies have revealed potentially interesting effects of several compounds in vitro and in laboratory animal models in vivo. ${ }^{28}$ These compounds were mainly derived from screenings against Plasmodium. Their application against Neospora would thus constitute a good example of drug repurposing. ${ }^{29}$

\section{Identification of suitable chemotherapeutics}

The strategies to identify antiparasitic agents against apicomplexan parasites are discussed elsewhere. ${ }^{1,30}$ Briefly, drug candidates can be initially identified by in vitro tests, where suitable host cells (eg, fibroblasts) are infected with $N$. caninum tachyzoites in the presence of the test compounds or a solvent control. After a given time period, ie, when the controls show a high level of infection, the experiment is stopped and the tachyzoites are quantified by a suitable method.
On the one hand, quantitative real-time polymerase chain reaction will provide information on the respective parasite loads. However, a suitable alternative for drug screening is the transgenic $N$. caninum $\mathrm{Nc}-1$ isolate-derived strain expressing $E$. coli beta-galactosidase under the control of a GRA1 promoter. ${ }^{31}$ At first, these in vitro studies will provide inhibition constants ( $\mathrm{eg}, \mathrm{IC}_{50}$ values), and data concerning host cell toxicity can be obtained using standard viability assays such as AlamarBlue. Furthermore, in vitro studies allow to assess whether a compound is parasitocidal or parasitostatic, whether it affects intracellular parasites, extracellularly located parasites or both, and they are suitable to assess the risk of resistance formation. Combined with morphological and structural investigations (eg, scanning electron microscopy and transmission electron microscopy), such in vitro studies can provide an initial characterization of the effects of a given compound. An example of a detailed study dealing with such aspects has been performed with $T$. gondii strains and pentamidine derivatives. ${ }^{32}$

In vivo drug assessments in mice can be performed using the same models as described earlier for the vaccine studies. Ideally, a standardized mouse model should be used in order to render different experiments with different compounds performed in different laboratories comparable. At best, only compounds that have been characterized in terms of their toxicity, stability, pharmacokinetic properties, and bioavailability are used for in vivo experiments. After inoculation of $N$. caninum tachyzoites, one should ideally allow the parasite 2-3 days to establish the infection prior to initiation of treatment, and protective effects against acute infection and against placental transmission are analyzed. In the latter case, pregnant mice are infected and treated during pregnancy. Since it cannot be ruled out that a given compound could affect pregnancy and offspring, in some cases, controls with uninfected dams have to be included.

\section{Effective compounds against neosporosis - an overview}

Selected studies on drugs against neosporosis are compiled in Table 3. Most experimental treatments have been performed with toltrazuril, a triazinone derivative effective against various coccidians including Eimeria, ${ }^{33}$ and commercialized under the trivial name Baycox ${ }^{\mathrm{TM}}$. The mode of action of toltrazuril and of its main metabolite toltrazuril sulfone (ponazuril) is not only related to the inhibition of dihydroorotate dehydrogenase and therefore pyrimidine biosynthesis, but also to the inhibition of the respiratory chain of the parasite. ${ }^{34}$ Whereas the effects against coccidian 
Table 3 Summary of selected studies with chemotherapeutics against neosporosis. If not otherwise mentioned, in vivo studies were performed with mice

\begin{tabular}{|c|c|c|c|c|c|}
\hline Compound & Class & Ref & Year & Type & Result \\
\hline Toltrazuril and ponazuril & Triazinone & 85 & 2001 & In vivo & $\begin{array}{l}\text { Protection against cerebral infection by daily application } \\
(20 \mathrm{mg} / \mathrm{kg}) \text { in drinking water. }\end{array}$ \\
\hline Ponazuril & & 86 & 2002 & In vivo & $\begin{array}{l}\text { Protection against symptoms in calves, lower parasite burden in } \\
\text { organs. }\end{array}$ \\
\hline Toltrazuril & & 87 & 2004 & In vivo & $\begin{array}{l}\text { Protection only in immunocompetent mice, no protection in } \\
\text { immune-impaired mice. }\end{array}$ \\
\hline Toltrazuril & & 88 & 2005 & In vivo & Reduction of placental transmission. \\
\hline Toltrazuril & & 89 & 2006 & In vivo & $\begin{array}{l}\text { Treatment of congenitally infected calves does not affect } \\
\text { seropositivity. }\end{array}$ \\
\hline Toltrazuril & & 90 & 2008 & In vitro & Treatment with $30 \mu \mathrm{g} / \mathrm{mL}$ during 14 days is parasitocidal. \\
\hline Toltrazuril & & 91 & 2009 & In vivo & Reduction of placental transmission ( $3 \times$ treatment with $30 \mathrm{mg} / \mathrm{kg}$ ). \\
\hline Toltrazuril & & 92 & 2015 & In vivo & No reduction of vertical transmission in artificially infected ewes. \\
\hline Nitro- and bromo-thiazolides & Thiazolides & 93 & 2005 & In vitro & Inhibition of proliferation is independent of nitro group. \\
\hline Nitro- and bromo-thiazolides & & 94 & 2007 & In vitro & Induction of egress of tachyzoites from infected cells. \\
\hline Nitazoxanide & & 95 & 2011 & In vivo & 150 mg/kg/day, po has no effect, ip kills the mice. \\
\hline DB750 & Dicationic arylimidamide & 95 & 2011 & In vivo & $\begin{array}{l}2 \mathrm{mg} / \mathrm{kg} / \text { day, ip is well supported, better survival, reduction of } \\
\text { cerebral parasite burden. }\end{array}$ \\
\hline DB745 & & 96 & 2012 & $\begin{array}{l}\text { In vitro } \\
\text { In vivo }\end{array}$ & $\begin{array}{l}\mathrm{IC}_{50} 80 \mathrm{nM} \text {. } \\
\text { Reduction of cerebral burden in mice after I4-day daily } \\
\text { application. }\end{array}$ \\
\hline Mefloquine & Trifluoromethylinoline & 28 & 2011 & In vitro & $\mathrm{IC}_{50} 0.5 \mu \mathrm{M}, \mathrm{EC}_{50}$ for HFF $3 \mu \mathrm{M}$ \\
\hline Miltefosine & Alkylphosphocholine & 97 & 2012 & $\begin{array}{l}\text { In vitro } \\
\text { In vivo }\end{array}$ & $\begin{array}{l}\mathrm{IC}_{50} 5.2 \mu \mathrm{M} \text {. Treatment with } 25 \mu \mathrm{M} \text { for } 20 \text { hours parasitocidal. } \\
\text { Reduction of symptoms and of cerebral burden. }\end{array}$ \\
\hline Artemisone & Sesquiterpene lactone & 98 & 2012 & $\begin{array}{l}\text { In vitro } \\
\text { In vivo } \\
\text { (gerbil) }\end{array}$ & $\begin{array}{l}\text { Inhibition of infection by } 15 \mathrm{mg} / \mathrm{L} \text {. Partial clearance of preinfected } \\
\text { cells by } 50 \mathrm{mg} / \mathrm{L} \text {. } \\
\text { Reduction of symptoms and of cerebral burden. }\end{array}$ \\
\hline Ruthenium & Heavy metal & 99 & 2013 & In vitro & $\begin{array}{l}\mathrm{IC}_{50} \text { approximately } 10 \mathrm{~nm} \text {. Parasitocidal activity only by long- } \\
\text { term-treatment with } 100 \mathrm{nM} \text {. }\end{array}$ \\
\hline Bumped kinase inhibitors & $\begin{array}{l}\text { Substituted } \\
\text { pyrazolopyrimidines }\end{array}$ & 100 & 2014 & $\begin{array}{l}\text { In vitro } \\
\text { In vivo }\end{array}$ & $\begin{array}{l}\text { Good structure-activity correlation. } \mathrm{IC}_{50} \text { approximately } 100 \mathrm{nM} \text {. } \\
\text { Inhibition of infection. } \\
\text { Reduction of symptoms and cerebral parasite burden. }\end{array}$ \\
\hline Bumped kinase inhibitor 1294 & & 44 & 2015 & In vivo & Reduction of vertical transmission in pregnant BALB/c mice. \\
\hline Buparvaquone & Naphtoquinone & 101 & 2015 & $\begin{array}{l}\text { In vitro } \\
\text { In vivo }\end{array}$ & $\begin{array}{l}\mathrm{IC}_{50} \sim 5 \mathrm{nM}, \mathrm{IC}_{100} \mathrm{I00} \mathrm{nM} \text { (short term). } \\
\text { Long-term adaptation to } 100 \mathrm{nM} \text {. Parasitocidal activity by } \\
6 \text { days treatment with I } \mu \mathrm{M} \text {. } \\
\text { Prevention of acute neosporosis. }\end{array}$ \\
\hline
\end{tabular}

Abbreviations: $\mathrm{EC}_{50}$, half maximal effective concentration; $\mathrm{IC}_{50}$, half maximal inhibitory concentration; $\mathrm{IC}_{100}$, maximal inhibitory concentration; ip, intraperitoneal; po, oral.

infections are well documented in poultry ${ }^{35}$ as well as in cattle, ${ }^{36}$ it remains unclear whether toltrazuril is a suitable drug against neosporosis in cattle (Table 3 ). Thiazolides, including nitazoxanide, the mother compound of this class, ${ }^{37}$ exhibited interesting effects against $N$. caninum in vitro, but failed in vivo when orally applied, and even showed acute toxicity when applied intraperitoneally (Table 3). This is most likely due to induction of host cell apoptosis. ${ }^{38}$ The most promising drug candidates for neosporosis treatment come from compounds initially developed against Plasmodium such as artemisinin and pentamidine derivatives ${ }^{30}$ and spiroindolones, a novel class of antimalarial ${ }^{39}$ inhibiting a $\mathrm{Na}^{+}$-efflux pump in Plasmodium. ${ }^{40}$ Among other drug targets, calcium-dependent kinase I (CDPK1) in N. caninum deserves particular interest. CDPK1 is essential for microneme secretion, host cell invasion, and egress of T. gondii. ${ }^{41} \mathrm{~A}$ particular class of inhibitors, bumped kinase inhibitors, has bulky C3 aryl substituents, which can enter and block a hydrophobic pocket in the adenosine triphosphate binding site due to a small (glycine) gatekeeper residue. BKIs selectively inhibit CDPK1 from apicomplexans, exhibiting a good structureactivity relationship, ${ }^{42,43}$ but do not inhibit mammalian kinases because these have larger gatekeeper residues adjacent to the hydrophobic pocket thereby blocking the entry of the bulky C3 aryl group. Some BKIs, especially BKI-1294, exhibited excellent effectiveness against $N$. caninum in vitro and in vivo (Table 3). They are, however, not directly parasitocidal: only after long-term in vitro treatment of infected human 
foreskin fibroblast monolayers for more than 20 days at 2.5 $\mu$ M BKI-1294, parasitocidal effects have been observed. Similar findings have been obtained for different strains of T. gondii, where death of intracellular parasites is preceded by the formation of large, multinucleated complexes with a deregulated gene expression as evidenced by the expression of bradyzoite as well as tachyzoite antigens. ${ }^{44} \mathrm{~A}$ similar induction of bradyzoite antigen expression was observed when treating $N$. caninum-infected fibroblast monolayers with artemisone and respective derivatives. ${ }^{45}$

\section{Toward a strategy against neosporosis}

During the last decade, a number of in vitro and in vivo studies revealed some promising vaccine and drug candidates against neosporosis. None of them could, however, achieve full protection against transplacental transmission of $N$. caninum, the goal that should ultimately be achieved in cattle. Nevertheless, the promising results of both approaches could potentially be translated into a combined immuno-chemotherapeutical approach. The simplest model of an immune-chemotherapy would consist in applying a live- or attenuated vaccine together with a compound with high efficacy as shown in previous in vitro and in vivo studies. Such an approach has long been developed to vaccinate against theileriosis, with cattle being inoculated with live sporozoites and immediately treated with buparvaquone, the only drug currently available against Theileria parva and Theileria annulata, so far. ${ }^{46,47}$

Another model could consist in applying suitable chemotherapeutics together with polypeptides acting as classical vaccines or immune-stimulators. Recombinant proteins produced in E. coli or via another suitable expression system may contain impurities and are very expensive, especially when produced in high purity at large scales. On the other hand, the chemosynthesis of peptides has become increasingly cost-effective. Highly antigenic peptides could thus be produced by chemosynthesis, coupled to a high molecular weight carrier to render them immunogenic and/or to a suitable TLR-ligand, ${ }^{48,49}$ and could then be coapplied with a suitable chemotherapeutic agent.

Taken together, these encouraging results indicate that the ultimate goal of a one-shot therapy against neosporosis in cattle could become feasible. More in vitro as well as in vivo research using appropriate and, most importantly, standardized animal model is, however, required to reach this goal.

\section{Acknowledgments}

We gratefully acknowledge the financial support by a combined NIH/USDA program (dual use therapeutics for cryptosporidiosis, toxoplasmosis, and neosporosis; grant no 1 R01 HD080670_01), and the Swiss National Science Foundation (grant no 310030_146162).

\section{Disclosure}

The authors report no conflicts of interest in this work.

\section{References}

1. Müller J, Hemphill A. In vitro culture systems for the study of apicomplexan parasites in farm animals. Int $J$ Parasitol. 2013;43(2): $115-124$.

2. Hemphill A, Debache K, Monney T, et al. Proteins mediating the Neospora caninum-host cell interaction as targets for vaccination. Front Biosci (Elite Ed). 2013;5:23-36.

3. Hemphill A, Vonlaufen N, Naguleswaran A. Cellular and immunological basis of the host-parasite relationship during infection with Neospora caninum. Parasitology. 2006;133(Pt 3):261-278.

4. Buxton D, McAllister MM, Dubey JP. The comparative pathogenesis of neosporosis. Trends Parasitol. 2002;18:546-552.

5. Dubey JP. Review of Neospora caninum and neosporosis in animals. Korean J Parasitol. 2003;41(1):1-16.

6. Petersen E, Lebech M, Jensen L, et al. Neospora caninum infection and repeated abortions in humans. Emerg Infect Dis. 1999;5(2):278-280.

7. Gondim LF. Neospora caninum in wildlife. Trends Parasitol. 2006; 22(6):247-252.

8. Rosypal AC, Lindsay DS. The sylvatic cycle of Neospora caninum: where do we go from here? Trends Parasitol. 2005;21(10):439-440.

9. Reichel MP, Alejandra Ayanegui-Alcérreca M, Gondim LF, Ellis JT. What is the global economic impact of Neospora caninum in cattle - the billion dollar question. Int J Parasitol. 2012;43:133-142.

10. Häsler B, Stark KD, Sager H, Gottstein B, Reist M. Simulating the impact of four control strategies on the population dynamics of $\mathrm{NeO}-$ spora caninum infection in Swiss dairy cattle. Prev Vet Med. 2006; 77(3-4):254-283.

11. Häsler B, Regula G, Stark KD, Sager H, Gottstein B, Reist M. Financial analysis of various strategies for the control of Neospora caninum in dairy cattle in Switzerland. Prev Vet Med. 2006;77(3-4):230-253.

12. Reichel MP, Ellis JT. If control of Neospora caninum infection is technically feasible does it make economic sense? Vet Parasitol. 2006;142(1-2):23-34.

13. Zhang NZ, Chen J, Wang M, Petersen E, Zhu XQ. Vaccines against Toxoplasma gondii: new developments and perspectives. Expert Rev Vaccines. 2013;12(11):1287-1299.

14. Reichel MP, Ellis JT. Neospora caninum - how close are we to development of an efficacious vaccine that prevents abortion in cattle? Int $J$ Parasitol. 2009;39(11):1173-1187.

15. Monney T, Hemphill A. Vaccines against neosporosis: what can we learn from the past studies? Exp Parasitol. 2014;140:52-70.

16. Striepen B, Jordan CN, Reiff S, van Dooren GG. Building the perfect parasite: cell division in apicomplexa. PLoS Pathog. 2007; 3(6): 7 78.

17. Singh $\mathrm{S}$, Chitnis CE. Signalling mechanisms involved in apical organelle discharge during host cell invasion by apicomplexan parasites. Microbes Infect. 2012;14(10):820-824.

18. Lei T, Wang H, Liu J, Nan H, Liu Q. ROP18 is a key factor responsible for virulence difference between Toxoplasma gondii and Neospora caninum. PLoS One. 2014;9(6):e99744.

19. Debache K, Guionaud C, Alaeddine F, Mevissen M, Hemphill A. Vaccination of mice with recombinant NcROP2 antigen reduces mortality and cerebral infection in mice infected with Neospora caninum tachyzoites. Int J Parasitol. 2008;38(12):1455-1463.

20. Srinivasan S, Müller J, Suana A, Hemphill A. Vaccination with microneme protein NcMIC4 increases mortality in mice inoculated with Neospora caninum. J Parasitol. 2007;93(5):1046-1055. 
21. Naguleswaran A, Cannas A, Keller N, et al. Neospora caninum microneme protein NcMIC3: secretion, subcellular localization, and functional involvement in host cell interaction. Infect Immun. 2001; 69(10):6483-6494.

22. Pandey AK, Reddy KS, Sahar T, et al. Identification of a potent combination of key Plasmodium falciparum merozoite antigens that elicit strain-transcending parasite-neutralizing antibodies. Infect Immun. 2013;81(2):441-451

23. Basto AP, Badenes M, Almeida SC, et al. Immune response profile elicited by the model antigen ovalbumin expressed in fusion with the bacterial OprI lipoprotein. Mol Immunol. 2015;64(1):36-45.

24. Basto AP, Leitao A. Targeting TLR2 for vaccine development. J Immunol Res. 2014;2014:619410.

25. Estes DM, Brown WC. Type 1 and type 2 responses in regulation of Ig isotype expression in cattle. Vet Immunol Immunopathol. 2002; 90(1-2):1-10.

26. Staska LM, Davies CJ, Brown WC, et al. Identification of vaccine candidate peptides in the NcSRS2 surface protein of Neospora caninum by using CD4+ cytotoxic T lymphocytes and gamma interferon-secreting T lymphocytes of infected holstein cattle. Infect Immun. 2005;73(3):1321-1329.

27. Dubey JP, Schares G, Ortega-Mora LM. Epidemiology and control of neosporosis and Neospora caninum. Clin Microbiol Rev. 2007;20(2): 323-367.

28. Müller J, Hemphill A. Drug target identification in intracellular and extracellular protozoan parasites. Curr Top Med Chem. 2011; 11(16):2029-2038.

29. Sateriale A, Bessoff K, Sarkar IN, Huston CD. Drug repurposing: mining protozoan proteomes for targets of known bioactive compounds J Am Med Inform Assoc. 2014;21(2):238-244

30. Müller J, Hemphill A. New approaches for the identification of drug targets in protozoan parasites. Int Rev Cell Mol Biol. 2013;301:359-401.

31. Howe DK, Sibley LD. Development of molecular genetics for Neospora caninum: a complementary system to Toxoplasma gondii. Methods 1997;13(2):123-133.

32. Kropf C, Debache K, Rampa C, et al. The adaptive potential of a survival artist: characterization of the in vitro interactions of Toxoplasma gondii tachyzoites with di-cationic compounds in human fibroblast cell cultures. Parasitology. 2012;139:208-220.

33. Steinfelder S, Lucius R, Greif G, Pogonka T. Treatment of mice with the anticoccidial drug Toltrazuril does not interfere with the development of a specific cellular intestinal immune response to Eimeria falciformis. Parasitol Res. 2005;97(6):458-465.

34. Harder A, Haberkorn A. Possible mode of action of toltrazuril: studies on two Eimeria species and mammalian and Ascaris suum enzymes Parasitol Res. 1989;76(1):8-12.

35. Mathis GF, Froyman R, Irion T, Kennedy T. Coccidiosis control with toltrazuril in conjunction with anticoccidial medicated or nonmedicated feed. Avian Dis. 2003;47(2):463-469.

36. Mundt HC, Bangoura B, Mengel H, Keidel J, Daugschies A. Control of clinical coccidiosis of calves due to Eimeria bovis and Eimeria zuernii with toltrazuril under field conditions. Parasitol Res. 2005;97 (Suppl 1):S134-S142.

37. Hemphill A, Müller N, Müller J. Thiazolides, a novel class of antiinfective drugs, effective against viruses, bacteria, intracellular and extracellular protozoan parasites and proliferating mammalian cells Antiinfect Agents. 2013;11:22-30.

38. Müller J, Sidler D, Nachbur U, Wastling J, Brunner T, Hemphill A. Thiazolides inhibit growth and induce glutathione-S-transferase Pi (GSTP1)-dependent cell death in human colon cancer cells. Int $J$ Cancer. 2008;123(8):1797-1806.

39. Rottmann M, McNamara C, Yeung BK, et al. Spiroindolones, a potent compound class for the treatment of malaria. Science. 2010;329(5996): 1175-1180.

40. Spillman NJ, Allen RJ, McNamara CW, et al. $\mathrm{Na}(+)$ regulation in the malaria parasite Plasmodium falciparum involves the cation ATPase PfATP4 and is a target of the spiroindolone antimalarials. Cell Host Microbe. 2013;13(2):227-237.
41. Lourido S, Shuman J, Zhang C, Shokat KM, Hui R, Sibley LD. Calciumdependent protein kinase 1 is an essential regulator of exocytosis in Toxoplasma. Nature. 2010;465(7296):359-362.

42. Keyloun KR, Reid MC, Choi R, et al. The gatekeeper residue and beyond: homologous calcium-dependent protein kinases as drug development targets for veterinarian Apicomplexa parasites. Parasitology. 2014;141(11):1499-1509.

43. Zhang Z, Ojo KK, Vidadala R, et al. Potent and selective inhibitors of CDPK1 from and based on a 5-aminopyrazole-4-carboxamide scaffold. ACS Med Chem Lett. 2014;5(1):40-44.

44. Winzer P, Müller J, Aguado-Martínez A, et al. In vitro and in vivo effects of the bumped kinase inhibitor 1294 in the related cyst-forming apicomplexans Toxoplasma gondii and Neospora caninum. Antimicrob Agents Chemother. Epub 2015 Jul 27.

45. Müller J, Balmer V, Winzer P, et al. In vitro effects of new artemisinin derivatives in Neospora caninum-infected human fibroblasts. Int $J$ Antimicrob Agents. 2015;46:88-93.

46. Brown CG. Control of tropical theileriosis (Theileria annulata infection) of cattle. Parassitologia. 1990;32(1):23-31.

47. Mutugi JJ, Young AS, Maritim AC, Linyonyi A, Mbogo SK, Leitch BL. Immunization of cattle using varying infective doses of Theileria parva lawrencei sporozoites derived from an African buffalo (Syncerus caffer) and treatment with buparvaquone. Parasitology. 1988; 96(Pt 2):391-402.

48. Xin H, Cartmell J, Bailey JJ, Dziadek S, Bundle DR, Cutler JE. Self-adjuvanting glycopeptide conjugate vaccine against disseminated candidiasis. PLoS One. 2012;7(4):e35106.

49. Casal JI, Langeveld JP, Cortes E, et al. Peptide vaccine against canine parvovirus: identification of two neutralization subsites in the $\mathrm{N}$ terminus of VP2 and optimization of the amino acid sequence. $J$ Virol. 1995;69(11):7274-7277.

50. Kasper LH, Khan IA. Antigen-specific CD8+ T cells protect against lethal toxoplasmosis in mice infected with Neospora caninum. Infect Immun. 1998;66(4):1554-1560.

51. Cannas A, Naguleswaran A, Müller N, Eperon S, Gottstein B, Hemphill A. Vaccination of mice against experimental Neospora caninum infection using NcSAG1- and NcSRS2-based recombinant antigens and DNA vaccines. Parasitology. 2003;126(Pt 4): 303-312.

52. Cannas A, Naguleswaran A, Müller N, Gottstein B, Hemphill A. Reduced cerebral infection of Neospora caninum-infected mice after vaccination with recombinant microneme protein NcMIC3 and ribi adjuvant. J Parasitol. 2003;89(1):44-50.

53. Alaeddine F, Keller N, Leepin A, Hemphill A. Reduced infection and protection from clinical signs of cerebral neosporosis in $\mathrm{C} 57 \mathrm{BL} / 6$ mice vaccinated with recombinant microneme antigen NcMIC1. J Parasitol. 2005;91(3):657-665.

54. Haldorson GJ, Mathison BA, Wenberg K, et al. Immunization with native surface protein NcSRS2 induces a Th2 immune response and reduces congenital Neospora caninum transmission in mice. Int $J$ Parasitol. 2005;35(13):1407-1415.

55. Ramamoorthy S, Lindsay DS, Schurig GG, et al. Vaccination with gamma-irradiated Neospora caninum tachyzoites protects mice against acute challenge with $N$. caninum. J Eukaryot Microbiol. 2006;53(2):151-156.

56. Ramamoorthy S, Sanakkayala N, Vemulapalli R, et al. Prevention of lethal experimental infection of C57BL/6 mice by vaccination with Brucella abortus strain RB51 expressing Neospora caninum antigens. Int J Parasitol. 2007;37(13):1521-1529.

57. Ramamoorthy S, Duncan R, Lindsay DS, Sriranganathan N. Optimization of the use of C57BL/6 mice as a laboratory animal model for Neospora caninum vaccine studies. Vet Parasitol. 2007;145(3-4): 253-259.

58. Ramamoorthy S, Sanakkayala N, Vemulapalli R, et al. Prevention of vertical transmission of Neospora caninum in C57BL/6 mice vaccinated with Brucella abortus strain RB51 expressing $N$. caninum protective antigens. Int J Parasitol. 2007;37(13):1531-1538. 
59. Debache K, Alaeddine F, Guionaud C, et al. Vaccination with recombinant NcROP2 combined with recombinant NcMIC1 and NcMIC3 reduces cerebral infection and vertical transmission in mice experimentally infected with Neospora caninum tachyzoites. Int J Parasitol. 2009;39(12):1373-1384.

60. Lopez-Perez IC, Collantes-Fernandez E, Aguado-Martinez A, Rodriguez-Bertos A, Ortega-Mora LM. Influence of Neospora caninum infection in BALB/c mice during pregnancy in post-natal development. Vet Parasitol. 2008;155(3-4):175-183.

61. Zhang G, Huang X, Boldbaatar D, et al. Construction of Neospora caninum stably expressing TgSAG1 and evaluation of its protective effects against Toxoplasma gondii infection in mice. Vaccine. 2010; 28(45):7243-7247.

62. Debache K, Guionaud C, Alaeddine F, Hemphill A. Intraperitoneal and intra-nasal vaccination of mice with three distinct recombinant Neospora caninum antigens results in differential effects with regard to protection against experimental challenge with Neospora caninum tachyzoites. Parasitology. 2010;137(2):229-240.

63. Marugan-Hernandez V, Ortega-Mora LM, Aguado-Martinez A, Jimenez-Ruiz E, Alvarez-Garcia G. Transgenic Neospora caninum strains constitutively expressing the bradyzoite NcSAG4 protein proved to be safe and conferred significant levels of protection against vertical transmission when used as live vaccines in mice. Vaccine. 2011; 29(44):7867-7874.

64. Tuo W, Zhao Y, Zhu D, Jenkins MC. Immunization of female BALB/c mice with Neospora cyclophilin and/or NcSRS2 elicits specific antibody response and prevents against challenge infection by Neospora caninum. Vaccine. 2011;29(13):2392-2399.

65. Monney T, Rutti D, Schorer M, et al. RecNcMIC3-1-R is a micronemeand rhoptry-based chimeric antigen that protects against acute neosporosis and limits cerebral parasite load in the mouse model for Neospora caninum infection. Vaccine. 2011;29(40):6967-6975.

66. Rojo-Montejo S, Collantes-Fernandez E, Lopez-Perez I, Risco-Castillo V, Prenafeta A, Ortega-Mora LM. Evaluation of the protection conferred by a naturally attenuated Neospora caninum isolate against congenital and cerebral neosporosis in mice. Vet Res. 2012;43:62.

67. Jimenez-Ruiz E, Alvarez-Garcia G, Aguado-Martinez A, et al. Low efficacy of NcGRA7, NcSAG4, NcBSR4 and NcSRS9 formulated in poly-epsilon-caprolactone against Neospora caninum infection in mice. Vaccine. 2012;30(33):4983-4992.

68. Mansilla FC, Franco-Mahecha OL, Lavoria MA, et al. The immune enhancement of a novel soy lecithin/beta-glucans based adjuvant on native Neospora caninum tachyzoite extract vaccine in mice. Vaccine. 2012;30(6):1124-1131.

69. Monney T, Grandgirard D, Leib SL, Hemphill A. Use of a Th1 stimulator adjuvant for vaccination against Neospora caninum infection in the pregnant mouse model. Pathogens. 2013;2(2):193-208.

70. Jia LJ, Zhang SF, Qian NC, et al. Generation and immunity testing of a recombinant adenovirus expressing NcSRS2-NcGRA7 fusion protein of bovine Neospora caninum. Korean J Parasitol. 2013;51(2):247-253.

71. Uchida M, Nagashima K, Akatsuka Y, et al. Comparative study of protective activities of Neospora caninum bradyzoite antigens, NcBAG1, NcBSR4, NcMAG1, and NcSAG4, in a mouse model of acute parasitic infection. Parasitol Res. 2013;112(2):655-663.

72. Debache K, Hemphill A. Differential effects of intranasal vaccination with recombinant NcPDI in different mouse models of Neospora caninum infection. Parasite Immunol. 2013;35(1):11-20.

73. Kato T, Otsuki T, Yoshimoto M, et al. Bombyx mori nucleopolyhedrovirus displaying Neospora caninum antigens as a vaccine candidate against N. caninum infection in mice. Mol Biotechnol. 2014;57(2):145-154.

74. Hecker YP, Coceres V, Wilkowsky SE, et al. A Neospora caninum vaccine using recombinant proteins fails to prevent foetal infection in pregnant cattle after experimental intravenous challenge. Vet Immunol Immunopathol. 2014;162(3-4):142-153.

75. Nishikawa Y, Ikeda H, Fukumoto S, et al. Immunization of dogs with a canine herpesvirus vector expressing Neospora caninum surface protein, NcSRS2. Int J Parasitol. 2000;30(11):1167-1171.
76. O'Handley RM, Morgan SA, Parker C, Jenkins MC, Dubey JP. Vaccination of ewes for prevention of vertical transmission of Neospora caninum. Am J Vet Res. 2003;64(4):449-452.

77. Williams DJ, Guy CS, Smith RF, et al. First demonstration of protective immunity against foetopathy in cattle with latent Neospora caninum infection. Int J Parasitol. 2003;33(10):1059-1065.

78. Jenkins MC, Tuo W, Dubey JP. Evaluation of vaccination with Neospora caninum protein for prevention of fetal loss associated with experimentally induced neosporosis in sheep. Am J Vet Res. 2004;65(10):1404-1408.

79. Romero JJ, Perez E, Frankena K. Effect of a killed whole Neospora caninum tachyzoite vaccine on the crude abortion rate of Costa Rican dairy cows under field conditions. Vet Parasitol. 2004;123(3-4):149-159.

80. Weston JF, Heuer C, Williamson NB. Efficacy of a Neospora caninum killed tachyzoite vaccine in preventing abortion and vertical transmission in dairy cattle. Prev Vet Med. 2012;103(2-3):136-144.

81. Mansilla FC, Czepluch W, Malacari DA, et al. Dose-dependent immunogenicity of a soluble Neospora caninum tachyzoite-extract vaccine formulated with a soy lecithin/beta-glucan adjuvant in cattle. Vet Parasitol. 2013;197(1-2):13-21.

82. Nishimura M, Kohara J, Kuroda Y, et al. Oligomannose-coated liposomeentrapped dense granule protein 7 induces protective immune response to Neospora caninum in cattle. Vaccine. 2013;31(35):3528-3535.

83. Rojo-Montejo S, Collantes-Fernandez E, Perez-Zaballos F, et al. Effect of vaccination of cattle with the low virulence $\mathrm{Nc}$-Spain $1 \mathrm{H}$ isolate of Neospora caninum against a heterologous challenge in early and mid-gestation. Vet Res. 2013;44:106.

84. Weber FH, Jackson JA, Sobecki B, et al. On the efficacy and safety of vaccination with live tachyzoites of Neospora caninum for prevention of neospora-associated fetal loss in cattle. Clin Vaccine Immunol. 2013; 20(1):99-105.

85. Gottstein B, Eperon S, Dai WJ, Cannas A, Hemphill A, Greif G. Efficacy of toltrazuril and ponazuril against experimental Neospora caninum infection in mice. Parasitol Res. 2001;87(1):43-48.

86. Kritzner S, Sager H, Blum J, Krebber R, Greif G, Gottstein B. An explorative study to assess the efficacy of toltrazuril-sulfone (ponazuril) in calves experimentally infected with Neospora caninum. Ann Clin Microbiol Antimicrob. 2002;1:4.

87. Ammann P, Waldvogel A, Breyer I, Esposito M, Müller N, Gottstein B. The role of B- and T-cell immunity in toltrazuril-treated C57BL/6 WT, microMT and nude mice experimentally infected with Neospora caninum. Parasitol Res. 2004;93(3):178-187.

88. Gottstein B, Razmi GR, Ammann P, Sager H, Muller N. Toltrazuril treatment to control diaplacental Neospora caninum transmission in experimentally infected pregnant mice. Parasitology. 2005; 130(Pt 1):41-48.

89. Haerdi C, Haessig M, Sager H, Greif G, Staubli D, Gottstein B. Humoral immune reaction of newborn calves congenitally infected with Neospora caninum and experimentally treated with toltrazuril. Parasitol Res. 2006;99(5):534-540.

90. Strohbusch M, Müller N, Hemphill A, Greif G, Gottstein B. NcGRA2 as a molecular target to assess the parasiticidal activity of toltrazuril against Neospora caninum. Parasitology. 2008;135(9):1065-1073.

91. Strohbusch M, Müller N, Hemphill A, Krebber R, Greif G, Gottstein B. Toltrazuril treatment of congenitally acquired Neospora caninum infection in newborn mice. Parasitol Res. 2009;104(6):1335-1343.

92. Syed-Hussain SS, Howe L, Pomroy WE, West DM, Hardcastle M, Williamson NB. Study on the use of toltrazuril to eliminate Neospora caninum in congenitally infected lambs born from experimentally infected ewes. Vet Parasitol. 2015;210(3-4):141-144.

93. Esposito M, Stettler R, Moores SL, et al. In vitro efficacies of nitazoxanide and other thiazolides against Neospora caninum tachyzoites reveal antiparasitic activity independent of the nitro group. Antimicrob Agents Chemother. 2005;49(9):3715-3723.

94. Esposito M, Moores S, Naguleswaran A, Müller J, Hemphill A. Induction of tachyzoite egress from cells infected with the protozoan Neospora caninum by nitro- and bromo-thiazolides, a class of broad-spectrum anti-parasitic drugs. Int J Parasitol. 2007;37(10):1143-1152. 
95. Debache K, Guionaud C, Kropf C, Boykin D, Stephens CE, Hemphill A. Experimental treatment of Neospora caninum-infected mice with the arylimidamide DB750 and the thiazolide nitazoxanide. Exp Parasitol. 2011;129(2):95-100.

96. Schorer M, Debache K, Barna F, et al. Di-cationic arylimidamides act against Neospora caninum tachyzoites by interference in membrane structure and nucleolar integrity and are active against challenge infection in mice. Int J Parasitol Drugs Drug Resist. 2012;2:109-120.

97. Debache K, Hemphill A. Effects of miltefosine treatment in fibroblast cell cultures and in mice experimentally infected with Neospora caninum tachyzoites. Parasitology. 2012;139(7):934-944.

98. Mazuz ML, Haynes R, Shkap V, et al. Neospora caninum: in vivo and in vitro treatment with artemisone. Vet Parasitol. 2012;187(1-2):99-104.
99. Barna F, Debache K, Vock CA, Küster T, Hemphill A. In vitro effects of novel ruthenium complexes in Neospora caninum and Toxoplasma gondii tachyzoites. Antimicrob Agents Chemother. 2013;57(11): $5747-5754$.

100. Ojo KK, Reid MC, Kallur Siddaramaiah L, et al. Neospora caninum calcium-dependent protein kinase 1 is an effective drug target for neosporosis therapy. PLoS One. 2014;9(3):e92929.

101. Müller J, Aguado-Martinez A, Manser V, et al. Buparvaquone is active against Neospora caninum in vitro and in experimentally infected mice. Int J Parasitol Drugs Drug Resist. 2015;5:16-25.
Reports in Parasitology

\section{Publish your work in this journal}

Reports in Parasitology is international, peer-reviewed, open access journal publishing original research, reports, reviews and commentaries on all areas of parasitology. The manuscript management system is completely online and includes a very quick and fair peer-review

\section{Dovepress}

system. Visit http://www.dovepress.com/testimonials.php to read real quotes from published authors. 